\title{
Miłosz | Krasnogruda. Opowieści wędrowców ${ }^{1}$
}

Marek Bernacki

TEKSTY DRUGIE 2017, NR 1, S. 139-145

DOI: 10.18318/td.2017.1.11

W 2012 roku nakładem Muzeum Okręgowego w Suwałkach ukazał się Przewodnik. Miłosz | Krasnogruda ${ }^{2}$. Autorem tej publikacji jest Zbigniew Fałtynowicz, starszy kustosz Muzeum Okręgowego w Suwałkach, badacz literatury współczesnej inspirowanej Suwalszczyzną i autor dwóch ważnych książek poświęconych autorowi Traktatu moralnego: Wieczorem wiatr. Czesław Miłosz i Suwalszczyzna (2007) oraz Dla Miłosza: Suwatki - Krasnogruda (2007). Całość została pomyślana jako opowieść o miejscu, które uformowało przyszłego noblistę i w jakimś stopniu za-

1 Recenzja książki: Z. Fałtynowicz Miłosz | Krasnogruda, wstęp P. Kłoczowski, oprac. graf. K. Kubicka, Wydawnictwo Fundacja Pogranicze, Sejny 2016.

2 Z. Fałtynowicz Przewodnik. Miłosz I Krasnogruda, wstęp P. Kłoczowski, Suwałki 2012, s. 47. (Pierwodruk Przewodnika... ukazał się w dwumiesięczniku literackim „Topos” 2011 nr 5.) O przewodniku tym pisałem na łamach "Świata i Słowa”, zob. M. Bernacki Krasnogruda Miłosza - o "Przewodniku” Zbigniewa Fałtynowicza [recenzja], „Świat i Słowo” 2013 nr 20, s. 307-311; przedruk: „Kroniki” kwartalny dokument wewnętrzny Muzeum im. Marii Konopnickiej w Suwałkach, $2012 \mathrm{nr} 4$ (13), s. 18-19.
Marek Bernacki prof. dr hab., dziekan Wydziału Humanistyczno-Społecznego Akademii Techniczno-Humanistycznej w Bielsku-Białej, prof. nadzwyczajny w Katedrze Literatury i Kultury Polskiej ATH, członek Komitetu Historycznoliterackiego PAN, Oddział w Katowicach. Ostatnio opublikował: Świat interpretować - konieczne zadanie. Studia o literaturze polskiej przełomu XXiXXI wieku (2014). Kontakt: marber2@ poczta.onet.pl 
ważyło na jego dalszych losach. Jak zauważył we Wstępie do omawianej książki Piotr Kłoczowski:

Przewodnik Zbigniewa Fałtynowicza pozostaje ważnym źródłem dla prawdziwej, nie zmitologizowanej historii narodzin inteligencji z historycznego rozpadu ziemiaństwa. Historia jak z Buddenbrooków, gdzie najmłodszy i najsłabszy ustanawia Krasnogrudę duchową formą życia. ${ }^{3}$

Cztery lata po ukazaniu się rzeczonego przewodnika nakładem Fundacji Pogranicze została wydana jego rozszerzona wersja książkowa pt. Miłosz | Krasnogruda ${ }^{4}$.

Najnowsze opracowanie Fałtynowicza niemal w całości powtarza pierwotny zapis, choć w niektórych miejscach autor dodaje nowe wątki lub wprowadza zmiany redakcyjne, jak np. we fragmencie poświęconym kolekcji malarskiej znajdującej się niegdyś w dworze krasnogrudzkim. W rozszerzonej wersji Przewodnika pojawiają się też nowe elementy graficzne oraz ilustracje, które wzmacniają opis od strony wizualnej. I tak, na stronie przytytułowej, tuż po Spisie treści, zamieszczono na dwóch stronach Mapę okolic Krasnogrudy z 1839 roku, zaś na stronie trzynastej pojawił się dużo większy fragment przedwojennej Mapy powiatu suwalskiego wydanej w 1929 roku przez Wojskowy Instytut Historyczny w skali 1:100 0oo. Na mapie tej można odnaleźć majątek Krasnogruda położony w bezpośredniej bliskości dwóch polodowcowych akwenów na pograniczu polsko-litewskim jeziora Gaładuś i jeziora Hołny. To właśnie tu, na niewielkim obszarze wśród malowniczych krajobrazów ziemi sejneńskiej, rozegrał się w latach 30. XX wieku dramatyczny epizod życia Czesława Miłosza, który - jak przekonująco dowodzi autor Przewodnika, zaważył na przyszłości poety i odegrał istotną rolę w twórczości noblisty.

Punktem wyjścia i osnową wszystkich rozważań pomieszczonych przez Zbigniewa Fałtynowicza jest fragment cytowanego przezeń przewodnika krajoznawczego i turystyczno-letniskowego Pojezierze Augustowsko-Suwalskie z 1937 roku:

2,5 km na wschód od jez. Gaładuś w pięknej pagórkowatej okolicy leży nad jez. Hołny maj. Krasnogruda, dawniej Eysymontów, potem Kunatów, obecnie p.p. Lipskich. Dwór drewniany, od frontu ganek na kolum-

3 Z. Fałtynowicz Przewodnik. Miłosz | Krasnogruda, s. 6.

4 Z. Fałtynowcz Miłosz | Krasnogruda, s. 45. 
nach, od ogrodu - przybudówka (alkierzyk) nadaje mu kształt litery L. Pochodzi z końca XVII w. Wewnątrz jadalnia o belkowanym suficie. Portrety rodzinne pędzla L. Janowskiej z lat 1910-[19]12. Kolekcja książek ze zbiorów St. Kunata (koniec XVIII wieku) oraz jego portret (sztych) ryt. w Paryżu 1832 r. Kolekcja sztychów królów polskich (ze zbioru Lessera). Sztych kardynała Jana Lipskiego (1690-1736), biskupa krakowskiego. W parku - jesiony i lipy 300-letnie.

We dworze pensjonat na 20 osób. Na pisemne zamówienie (poczta Sejny) wysyła się samochód do st. Augustów. Obok dworu 132 ha lasu (świerk, sosna). Na polu olbrzymi głaz granitowy. Zachodni brzeg jez. Hołny suchy i lesisty nadaje się do obozowania. ${ }^{5}$

Przywołując wypowiedź Czesława Miłosza z wywiadu opublikowanego na łamach pisma „Krajobrazy” (1989, nr 42): „Krasnogruda [...] była dla mnie miejscem wielu sprzecznych przeżyć i nie bardzo chciałbym o tym mówić. Niektóre sprawy wyjaśniłem w swoich książkach”, Fałtynowicz dopowiada znamienne słowa: „Miłoszowy księgozbiór jest po tej okolicy, o życiu jej mieszkańców i gości, przewodnikiem". Na potwierdzenie tego autor przytacza na kolejnych stronach swojego opracowania cytaty pochodzące z utworów noblisty, które w sposób mniej lub bardziej wyraźny były inspirowane wydarzeniami z okresu krasnogrudzkiego (w latach 30. XX wieku Miłosz przyjeżdżał do rodzinnego dworu nad jeziorem Hołny jako gimnazjalista, a później jako student, najczęściej w okresie wakacyjnym) lub odnosiły się do jego późniejszych pobytów na Suwalszczyźnie na przełomie lat 80. i 90. XX wieku (Miłosz odwiedzał te strony pięciokrotnie: 22-25 IX 1989, 6-8 VI 1992, 15-17 VI 1993, 26-28 VI 1994 i 25-28 VI 1997).

W pierwszej grupie utworów znalazły się wiersze dedykowane „pięknej kuzynce Eli" (czyli Gabrieli Kunat). Są to: napisana w okresie przedwojennym Pieśń oraz o trzydzieści lat późniejsza Elegia dla N.N., wiersz z 1958 roku Jak można zapomnieć, a także fragmenty poetycko-autobiograficznego Osobnego zeszytu (1977-1979, Sześciu wykładów wierszem (tu: Wykład I) i Nieobjętej ziemi, czyli utworów powstałych już po otrzymaniu Nagrody Nobla. Do grupy drugiej należy zaliczyć utwory pisane przez Miłosza po pierwszej, odbytej przez niego po wielu latach, podróży na Suwalszczyznę, czyli we wrześniu 1989 roku. Są to: eseistyczny Rok myśliwego, autobiograficzne

5 Cyt. za: Pojezierze Augustowsko-Suwalskie: przewodnik krajoznawczy i turystyczno-letniskowy, Suwałki 1937. 
wiersze Powrót, Do leszczyny i Bryczką o zmierzchu oraz Abecadło (tu hasło: "Krasnogruda").

Ważnym fragmentem książki jest szczegółowy opis Portretu P-ny K., czyli wizerunku Gabrieli Kunat, namalowanego w 1908 roku przez Ludomira Janowskiego (kolorowa reprodukcja tego dzieła została umieszczona na początku książki). Jak przypomina autor, obraz ten znalazł się w okazałym albumie Malarstwo polskie w odbitkach barwnych, który ukazał się w Warszawie w 1908 roku pod redakcją Stefana Kulikowskiego, właściciela Salonu Sztuk Pięknych, jednej z największych instytucji tego typu na ziemiach polskich w tamtym czasie. A oto fragment opisu portretu sporządzony współcześnie przez historyka sztuki Elizę Ptaszyńską:

Portret $P$-ny K., o formacie zbliżonym do kwadratu, wypełnia, lekko przesunięte w prawo, ustawione en face popiersie elegancko ubranej kobiety. Ciemna suknia z bufiastymi rękawami i dużym kwadratowym dekoltem, ozdobiona na piersiach broszą kontrastuje z jasną i ciepłą w kolorycie skórą szyi i ramion. Owalną, o regularnych rysach twarz okalają ciemne, rozdzielone po środku głowy włosy, upięte na bokach w duże pukle. $\mathrm{Na}$ głowie skośnie nałożony ciemny kapelusz z małą główką i dekoracyjnie wygiętym rondem. [...] Portret pozornie konwencjonalny jest kompozycją przemyślaną, odwołującą się do najlepszych tradycji portretu renesansowego. Głębokie, ciemne barwy stroju i włosów kontrastują z jasną karnacją skóry, skupiając wzrok widza na twarzy i szyi kobiety [...]. ${ }^{6}$

Portret ten, który wisiał na ścianie krakowskiego mieszkania poety przy ul. Bogusławskiego w ostatnich latach jego życia, przypominał autorowi Trzech zim nie tylko bliską krewną, ale także... kobietę, z którą romansował potajemnie podczas wakacyjnych pobytów w Krasnogrudzie. Ten ukrywany przed innymi domownikami tajemniczy związek (opisany po raz pierwszy przez Andrzeja Franaszka, autora książki Miłosz. Biografia) wyleczył „nieszczęsnego młodzika" z myśli samobójczych, które go dopadły po nieudanej przygodzie miłosnej z „rudowłosą nimfomanką" - jedną z letniczek przebywających na wczasach w Krasnogrudzie. Niezwykłe w tej historii jest też to, że w listopadzie 1977 roku, kiedy autor Doliny Issy mieszkał jeszcze w Berkeley, reprodukcję portretu „pięknej kuzynki” otrzymał od... jej męża Władysława Lipskiego. Ten, w liście skierowanym do Miłosza, napisał m.in.:

6 Z. Fałtynowicz Przewodnik. Miłosz | Krasnogruda, s. 21. 
Cześku Miły! - od szeregu lat nosiłem się z myślą, aby Ci zrobić upominek i zamówić u kogoś z dobrych malarzy wykonanie kopii spalonego podczas wojny pięknego portretu Eli pędzla Ludomira Janoty Janowskiego. [...] Jako pamiątkę zamierzchłej, lepszej przeszłości wysoko ją sobie ceniłem. Dziś u schyłku życia, Tobie ją przekazuję.7

Ważnym fragmentem obu wydań książki Zbigniewa Fałtynowicza jest opis okresu okupacji hitlerowskiej (a następnie sowieckiej), kiedy to wnętrze zabytkowego dworu krasnogrudzkiego wraz z cennym wyposażeniem, także z bogatym księgozbiorem zgromadzonym przez krewnych Czesława Miłosza, uległo niemalże całkowitej dewastacji ${ }^{8}$. Fałtynowicz przytacza głosy anonimowych świadków tamtych wydarzeń, które rozgrywały się w 1945 roku:

"Gdzie się podziały meble, fortepian, biblioteka? A bo ja wiem? Ktoś zbuchtożył. Albo Niemcy, albo Ruskie?”; „To Niemcy rozebrali wnętrza i zabrali fortepian. A to, co zostało, wzięli okoliczni gospodarze”; „A jak przyszli Ruscy, wycięli wszystkie drzewa, okopy robili... A meble państwa - piękne krzesła, olbrzymie dębowe stoły - wytargali pod stodołę. A co z tego sprzedali, co wywieźli, co spalili... Była we dworze biblioteka z dziada pradziada, ale Ruscy zwalili wszystkie książki na kupę i podpalili".'

Oprócz wątków biograficznych i historycznych czytelnik znajdzie też w książce Fałtynowicza wiele skrupulatnych opisów przyrody (np. parku czy drzewostanu dworu w Krasnogrudzie), jak choćby przytoczony przez autora fragment inwentaryzacji zieleni przeprowadzonej jesienią 1984 roku:

Park zagęścił się znacznie samosiewem, który zniekształcił pierwotny układ zieleni, zginęło dużo starych drzew, wycięte zostały drzewa rosnące niegdyś przy ganku dworu. Trawnik przed elewacją frontową dworu został zniszczony. Parkowy układ drogowy uległ całkowitemu zatarciu. ${ }^{10}$

7 Tamże, s. 24.

8 Śladem tego księgozbioru jest zakupiony przez Zbigniewa Fałtynowicza w 2010 roku w antykwariacie zbiór Szkiców historycznych Karola Szajnochy z 1876 roku, opatrzonych pieczęcią i nazwiskiem właścicielki: „Florentyna Kunatt” (zob. tamże, s. 26).

9 Tamże, s. 25-26. 
Wielką wartością książki Miłosz | Krasnogruda są zdjęcia pochodzące ze zbiorów rodzinnych Miłoszów i Kunatów, które Zbigniew Fałtynowicz zamieścił za zgodą Anthony'ego, syna Czesława Miłosza. Czytelnik może zatem zobaczyć fotografie dworu krasnogrudzkiego z 1935 roku, zdjęcia portretowe: Czesława Miłosza z lat 30. XX wieku, jego ciotki Elżbiety (Gabrieli) z Kunatów Lipskiej, siedzącej w swoim pokoju w Krasnogrudzie, pod portretem namalowanym przez Ludomira Janowskiego, oraz jej męża Władysława Lipskiego, siedzącego na werandzie dworu. W książce zamieszczono także unikatowe fotografie letników przyjeżdżających do Krasnogrudy i spacerujących aleją byłego parku krajobrazowego prowadzącą do przystani na brzegu jeziora Hołny. Ponadto można także obejrzeć zdjęcia wykonane w latach 30. XX wieku w lasach znajdujących się w majątku krasnogrudzkim, obraz ogromnego granitowego głazu narzutowego, wspomnianego przez poetę w Osobnym zeszycie, a także wzburzone fale jeziora Hołny, w którego wodach pływał młody Miłosz.

Pod koniec książki znajdują się trzy symboliczne fotografie. Jedna z nich, czarno-biała, pokazuje 83-letniego Miłosza stojącego na drewnianym pomoście jeziora Hołny, podpartego na lasce i wpatrzonego w przestrzeń na horyzoncie. Zdjęcie zostało wykonane w czerwcu 1994 roku w Krasnogrudzie. Są też dwie fotografie samego dworu - pierwsza, czarno-biała pochodzi z lat 6o. XX wieku, kiedy rodzinna posesja Miłoszów i Kunatów była zrujnowana i nic nie wskazywało na to, że przetrwa kolejne lata. Tuż obok niej wydawca zamieścił kolorowe zdjęcie dworu po renowacji przeprowadzonej w 2011 roku (Roku Miłosza). Dwór, nadzorowany przez Fundację Pogranicze, prowadzoną przez Krzysztofa i Małgorzatę Czyżewskich, od kilku lat jest siedzibą Międzynarodowego Centrum Dialogu. Na belce frontowej werandy odnowionego dworu widnieje napis, który jest cytatem z Oskara Władysława Miłosza, dalekiego krewnego Czesława i jego mistrza: „Bieda temu, kto wyrusza i nie powraca". W tym napisie łączą się symbolicznie drogi wszystkich wędrowców. W ślad za autorem wiersza Powrót wracają do miejsc, które ich ukształtowały, stając się znakiem rozpoznawczym tożsamości. 


\section{Abstract}

\section{Marek Bernacki}

UNIVERSITY OF BIELSKO-BIALA

Miłosz | Krasnogruda: Wanderers'Tales

Z. Fałtynowcz, Miłosz | Krasnogruda, introduction by P. Kłoczowski, graphic design by K. Kubicka, Wydawnictwo Fundacja Pogranicze, Sejny 2016.

\section{Keywords}

Czesław Miłosz, Krasnogruda manor, Zbigniew Fałtynowicz, biography 